\title{
Residual effect of imazapyr + imazapic on cotton grown in succession to soybean
}

\author{
Samia R. de S. Ribeiro ${ }^{1}$, Amanda dos S. Souza ${ }^{1}$, Jéssica F. L. Leal ${ }^{1}$, Junior Borella ${ }^{1}$,
} André L. S. Araujo ${ }^{1} \&$ Camila F. de Pinho ${ }^{1}$

\begin{abstract}
${ }^{1}$ Universidade Federal Rural do Rio de Janeiro/Instituto de Agronomia/Departamento de Fitotecnia. Seropédica, RJ, Brasil. E-mail: samiaribeiro.ufra@gmail.com ORCID: 0000-0002-7329-9029; amanda.engagronoma@gmail.com - ORCID: 0000-0002-8371-867X; jessica-agroleal@hotmail.com - ORCID: 0000-0001-6654-7998; borellaj@gmail.com - ORCID: 0000-0002-0745-5759; andre23.araujo@yahoo.com.br - ORCID: 0000-0001-5331-0924; camilafepi@hotmail.com (Corresponding
\end{abstract} author) - ORCID: 0000-0003-2861-2212

\begin{abstract}
The long residual period of pre-emergent herbicides can interfere with successor crops, causing a phenomenon named carryover. This study evaluated the residual effect of imazapyr + imazapic herbicides on cotton crop grown in succession to soybean. The experiment was conducted between September 2016 and March 2017, in a randomized block design with 4 replicates, where the treatments were four doses of imazapyr + imazapic, 75, 150, 225 and $300 \mathrm{~g}_{\text {a.i. }} \mathrm{ha}^{-1}$, and the control. The analyzed variables were chlorophyll a fluorescence, shoot height, root length and volume, dry shoot mass and root dry mass. The data were submitted to analysis of variance and Tukey's test, at $\mathrm{p} \leq 0.05$. The reduction in photosynthetic performance indexes for treatments of 150, 225 and $300 \mathrm{~g}$ a.i. ha ${ }^{-1}$ at 15 days after emergence (DAE) and of $75 \mathrm{~g} \mathrm{a.i} \mathrm{ha}{ }^{-1}$ at 60 DAE indicated a photoinhibitory effect of these herbicides on plants. However, shoot height, length, volume and root dry mass were not affected in the treatments tested. Therefore, the persistence of the herbicide in the soil was not enough to characterize a carryover effect in cotton 135 days after application (DAA).
\end{abstract}

Key words: Gossypium hirsutum L., imidazolinones, herbicides

\section{Efeito residual de imazapir + imazapic em algodão cultivado em sucessão à soja}

RESUMO: O longo período residual dos herbicidas pré-emergentes pode interferir em culturas sucessoras, ocasionando o fenômeno denominado de efeito residual (carryover). O trabalho teve como objetivo avaliar o efeito residual dos herbicidas imazapir + imazapic na cultura de algodão em sucessão à soja. O experimento foi conduzido entre setembro de 2016 a março de 2017, no delineamento em blocos, com quatro repetições, sendo os tratamentos quatro doses de imazapir + imazapic, 75, 150, 225 e $300 \mathrm{~g}$ i.a. ha $\mathrm{h}^{-1}$ e a testemunha. As variáveis analisadas foram fluorescência da clorofila a, altura da planta, comprimento e volume da raiz, massa seca da parte aérea e massa seca da raiz. Os dados gerados foram submetidos à análise da variância e ao teste de Tukey, a $\mathrm{p} \leq$ 0,05 de probabilidade. A diminuição nos índices de desempenho fotossintético no algodão nos tratamentos com doses de 150, 225 e 300 g i.a. ha ${ }^{-1}$ aos 15 dias após emergência (DAE), e com dose de 75 g i.a. ha ${ }^{-1}$ aos $60 \mathrm{DAE}$, indica o efeito fotoinibitório destes herbicidas sobre as plantas, entretanto, as variáveis altura da planta, comprimento, volume e massa seca da raiz não foram afetados nos tratamentos testados. Portanto, a persistência do herbicida no solo não foi suficiente para caracterizar o efeito residual (carryover) em algodão 135 dias após a aplicação (DAA).

Palavras-chave: Gossypium hirsutum L., imidazolinonas, herbicidas 


\section{INTRODUCTION}

Cotton (Gossypium hirsutum L.) is considered a highyielding crop and it is therefore widely cultivated in succession to soybean in Brazil. Rainfed and irrigated crops make Brazil the fifth largest cotton producing country in the world (Ramos et al., 2014). Herbicides have emerged as a tool for weed control, opening new possibilities for agricultural management, reducing costs and increasing yields (Silva et al., 2012; Abouziena \& Haggag, 2016).

The imazapyr + imazapic herbicides act by inhibiting the activity of acetolactate synthase (ALS), which is essential in the synthesis of branched-chain amino acids, leucine, valine and isoleucine. Microbial degradation is the main form of dissipation of imazapyr in soil, and its half-life time varies from 25-142 days depending on soil characteristics and environmental conditions (Senseman, 2007). Imidazolinones have residual and persistent characteristics, being relatively soluble in the soil solution and slow to degrade (Dovala \& Monteiro, 2013).

When the desirable bioactivity of an herbicide exceeds the crop cycle for which it was applied, a carryover effect occurs. The carryover effect is nowadays common due to the use of early and super early soybean cultivars, which, together with the desiccation techniques of the plants used to harvest soybeans and sow the successor crops, reduces the time between herbicide application in soybean cultivation and sowing of crops in succession (Dan et al., 2012).

Therefore, the aim of this work was to evaluate the residual activity of a formulated mixture of imazapyr + imazapic herbicide applied at pre-emergence in a soybean crop on the cotton cultivated in succession, through analysis of transient chlorophyll a fluorescence and biometric parameters obtained in the cotton plants.

\section{Material ANd Methods}

The experiment was carried out in a greenhouse at the Federal Rural University of Rio de Janeiro (UFRRJ), in the municipality of Seropédica, Rio de Janeiro state, Brazil $\left(22.7690^{\circ} \mathrm{S}, 43.6870^{\circ} \mathrm{W}\right)$, in a crop succession scheme, during the period of September 2016 - April 2017.

An experimental design of four replicates in randomized blocks was adopted, where the treatments consisted of four doses of a commercial imazapyr + imazapic herbicide: $1 / 2$ labelrecommended dose (75 $\mathrm{g}$ a.i. ha $\left.{ }^{-1}\right)$; full label-recommended dose (150 ga.i. ha $\left.^{-1}\right) ; 11 \frac{1}{2}$ label-recommended dose (225 ga.i. ha $\left.^{-1}\right)$; and double label-recommended dose (300 g a.i. ha $\mathrm{h}^{-1}$ ). In addition, a control treatment without herbicide application was included, for a total of 20 experimental units. Each experimental unit consisted of $5 \mathrm{~L}$ polyethylene pots, filled with seived soil, classified texturally as sandy loam soil classified as Planosol.
Soil samples were analyzed at the Soil Analysis Laboratory of the Department of Soils at the Federal University of Viçosa, MG, Brazil (Table 1).

The sowing of BRS $397 \mathrm{cv}$. soybean (BRZ11-6426 cv. line), of approximately a 110 days cycle, was performed in all pots on September 23, 2016; immediately after, the herbicides were applied (plant-applique system). Plant culture was managed according to technical recommendations. Herbicides were applied using a $\mathrm{CO}_{2}$ pressurized backpack sprayer equipped with four XR-110.015 flat-fan nozzles at a pressure of $280 \mathrm{kPa}$ and a speed of $3 \mathrm{~km} \mathrm{~h}^{-1}$, delivering an application volume of $150 \mathrm{~L} \mathrm{ha}^{-1}$.

Independent of the evaluated treatments, all the units were kept free of weeds during the crop cycle by manual weeding. Treatments related to pests, diseases, cover crops, and growth regulators were carried out according to agronomic monitoring and recommendations.

At 120 days after the herbicide application, soybean plants were harvested and removed from the pots. Cotton was sown 15 days after the soybean harvesting, on January 27, 2017. At 15 and 60 days after the cotton emergence (DAE), chlorophyll a fluorescence was analyzed. After $60 \mathrm{DAE}$, the stage of first floral bud emergence, plants were collected for measurements of shoot height $(\mathrm{SH})$, root length (RL), root volume (RV), dry shoot (DSM) and dry root mass (DRM).

$\mathrm{SH}$ was obtained by measuring the total length $(\mathrm{cm})$ of the aerial part from the transition between stem and shoot. RL was obtained by measuring the total root length $(\mathrm{cm})$ from stemroot transition. RV was measured by the test method $(\mathrm{mL})$. DSM and DRM were obtained (g) on an analytical balance after the tissues were oven dried with forced air circulation at $65^{\circ} \mathrm{C}$ to constant mass.

Chlorophyll a fluorescence transients were measured in dark-adapted leaves of plants using a Handy-PEA fluorimeter (Plant Efficiency Analyzer, Hansatech Instruments Ltd, UK). Intact leaves and fully expanded first leaf still attached to the plant were kept in the dark for at least 20 min with clips specially provided by the manufacturer, prior to fluorescence measurement. The polyphasic fluorescence rise (OJIP) was induced by 1 saturating red-light flash (peak at $650 \mathrm{~nm}$ ) at $3.000 \mu \mathrm{mol}$ photons $\mathrm{m}^{-2} \mathrm{~s}^{-1}$, and was measured during the first second of illumination $\left(10 \mu \mathrm{s}^{-1} \mathrm{~s}\right.$; Strasser \& Govindjee, 1992). The OJIP fluorescence transients were based on the polyphasic fast fluorescence rise from the lowest intensity minimum fluorescence $\left(\mathrm{F}_{\mathrm{O}}\right)$ to the highest intensity maximum fluorescence $\left(\mathrm{F}_{\mathrm{M}}\right.$; Tsimilli-Michael \& Strasser, 2008). The fluorescence intensities were determined at 50, 100 and $300 \mu \mathrm{s}$ $\left(\mathrm{F}_{50}, \mathrm{~F}_{100}\right.$, and $\mathrm{F}_{300} \mu \mathrm{s}$, respectively), 2 and $30 \mathrm{~ms}\left(\mathrm{~F}_{2}\right.$ and $\mathrm{F}_{30}$ $\mathrm{ms}$, respectively) and at $\mathrm{F}_{\mathrm{M}}$ (maximum fluorescence) using the JIP-test parameters. The intensities measured at $50 \mu \mathrm{s}, 2$ and $30 \mathrm{~ms}$ were considered to be the fluorescence transients $\mathrm{F}_{0}, \mathrm{~F}_{\mathrm{J}}$ and $\mathrm{F}_{\mathrm{I}}$, respectively.

The JIP test was applied to analyze the OJIP transients, using normalizations and subtractions to compare the samples

Table 1. Physical and chemical properties of the soil used in the experiment

\begin{tabular}{|c|c|c|c|c|c|c|c|c|}
\hline \multirow{2}{*}{$\begin{array}{c}\text { Textural } \\
\text { classification }\end{array}$} & \multirow{2}{*}{$\begin{array}{c}\mathrm{pH} \\
\mathrm{H}_{2} \mathrm{O}\end{array}$} & \multirow{2}{*}{$\begin{array}{c}\mathbf{P} \\
\left.(\mathrm{mg} \mathrm{dm})^{-3}\right)\end{array}$} & $K$ & $\mathrm{Ca}^{2+}$ & $\mathrm{Mg}^{2+}$ & $\mathrm{AL}^{+2}$ & $\mathrm{~T}$ & \multirow{2}{*}{$\begin{array}{c}\mathrm{OM}^{*} \\
(\text { dag kg-1) }\end{array}$} \\
\hline & & & \multicolumn{5}{|c|}{$\left(\mathrm{cmol}_{\mathrm{c}} \mathrm{dm}^{-3}\right)$} & \\
\hline Sandy loam & 5.80 & 37.20 & 0.197 & 2.33 & 0.65 & 0 & 3.18 & 0.25 \\
\hline
\end{tabular}

${ }^{\star} \mathrm{OM}$ - Organic matter = Organic carbon x 1.724; Walkley-Black method; T - Cation exchange capacity 
for the events reflected in the OJ, OI, and IP phases. The transients were normalized as relative variable fluorescence:

$$
\mathrm{W}_{\mathrm{t}}=\frac{\left(\mathrm{F}_{\mathrm{t}}-\mathrm{F}_{0}\right)}{\left(\mathrm{F}_{\mathrm{J}}-\mathrm{F}_{0}\right)}
$$

and

$$
\mathrm{W}_{\mathrm{OI}}=\frac{\left(\mathrm{F}_{\mathrm{t}}-\mathrm{F}_{0}\right)}{\left(\mathrm{F}_{\mathrm{I}}-\mathrm{F}_{0}\right)}
$$

where:

$\mathrm{W}_{\mathrm{t}}$ - relative variable fluorescence at the time $\mathrm{t}$ between $\mathrm{F}_{0}$ and $\mathrm{F}_{\mathrm{J}}$;

$\mathrm{W}_{\mathrm{OI}}$ - relative variable fluorescence between steps O (50 $\mu \mathrm{s})$ and $\mathrm{I}(30 \mathrm{~ms})$; and,

$\mathrm{F}_{\mathrm{t}}$ - fluorescence emission from a dark-adapted leaf at time $t$.

All data were subjected to analysis of variance (ANOVA; $\mathrm{p} \leq 0.05$ ); being significant by the $\mathrm{F}$ test, they were subjected to regression analysis (Table 2) and the Tukey test (Table 3 ) at 0.05 probability using the Sisvar statistical program.

\section{Results AND Discussion}

The cotton plants grown in soil treated in pre-emergence with the formulated mixture of imazapyr + imazapic herbicides did not show differences in SH, RL, RV and RDM among the tested treatments (data not shown). Plants cultivated in soil treated with imazapyr + imazapic at doses 75, 150, 225 and $300 \mathrm{~g}$ a.i. ha ${ }^{-1}$ showed a decrease in DSM relative to the control (Figure 1). Those grown in soil treated with $300 \mathrm{~g}^{\text {a.i. }} \mathrm{ha}^{-1}$

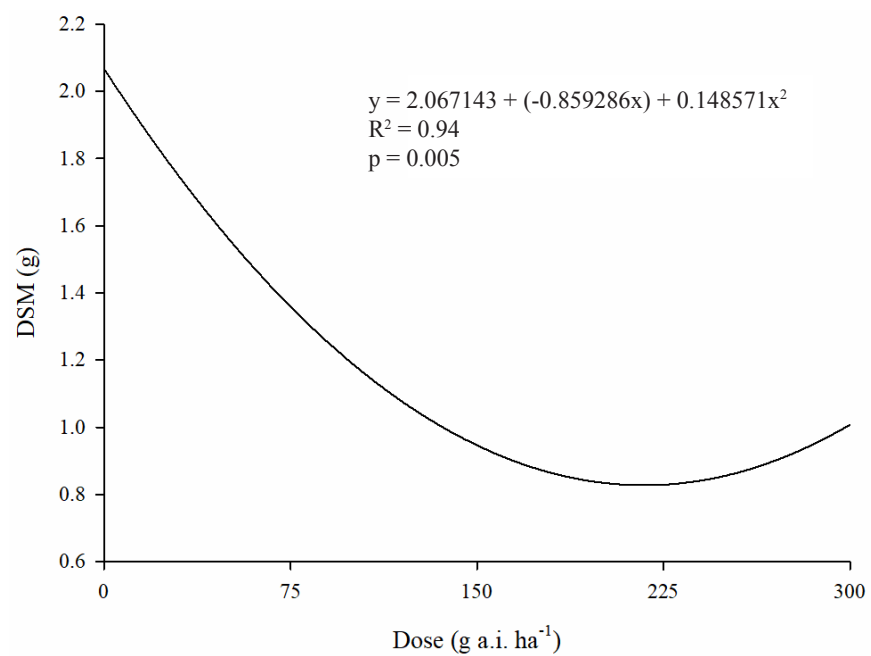

Figure 1. Dry shoot mass (DSM) of cotton plants grown under different doses of a commercial mixture of the herbicides imazapyr + imazapic residue 135 days after application of doses 75, 150, 225 and $300 \mathrm{~g}$ a.i. ha ${ }^{-1}$ of herbicide. Control plants were grown in parallel without the application of herbicide

had an aerial biomass reduction of $34.8 \%$ compared to plants cultivated in soil without herbicide residue.

The reduction of aerial biomass was a clear symptom of the mode of action of the herbicide in plants, as inhibition of ALS paralyzes apical growth by inhibiting the production of the branched-chain amino acids, valine, leucine and isoleucine, essential for plant development (Dan et al., 2012).

The formulated blend of the herbicides imazapyr + imazapic is widely used in the Clearfield System; therefore, residual effects on cotton evaluations are important when these herbicides are applied in pre-emergence in soybean. Grey et al. (2012) observed significant damage in cotton biomass grown in succession to wheat caused by sulfosulfuron, an ALS-

Table 2. Chlorophyll a fluorescence transients OJIP, obtained at 15 days after emergence (DAE) and 60 DAE of cotton cultivated

\begin{tabular}{|c|c|c|c|c|c|c|c|c|}
\hline \multirow{2}{*}{$\begin{array}{c}\text { Dose } \\
\left(\mathrm{g} \text { a.i. } h \mathrm{a}^{-1}\right)\end{array}$} & \multicolumn{4}{|c|}{$15 \mathrm{DAE}$} & \multicolumn{4}{|c|}{$60 \mathrm{DAE}$} \\
\hline & 0 & $\mathbf{J}$ & I & $\mathbf{P}$ & 0 & $\mathbf{J}$ & I & $\overline{\mathbf{P}}$ \\
\hline 0 & $420 \mathrm{ab}$ & $1044 \mathrm{a}$ & $1630 \mathrm{a}$ & $2194 a$ & $352 a b$ & $896^{\text {ns }}$ & $1144^{\mathrm{ns}}$ & $1460^{\text {ns }}$ \\
\hline 75 & 394 b & $917 \mathrm{~b}$ & $1495 \mathrm{bc}$ & $2072 a b$ & $380 \mathrm{a}$ & 936 & 1053 & 1412 \\
\hline 150 & $380 \mathrm{~b}$ & $929 \mathrm{~b}$ & $1403 \mathrm{c}$ & $1855 \mathrm{C}$ & $350 a b$ & 906 & 1142 & 1495 \\
\hline 225 & $447 \mathrm{a}$ & $946 \mathrm{~b}$ & $1541 \mathrm{ab}$ & 2013 bc & $316 \mathrm{~b}$ & 815 & 1098 & 1413 \\
\hline 300 & $386 \mathrm{~b}$ & $883 \mathrm{~b}$ & $1392 \mathrm{c}$ & $1864 \mathrm{C}$ & $350 a b$ & 862 & 1129 & 1588 \\
\hline CV (\%) & 4.41 & 4.10 & 3.44 & 3.83 & 7.04 & 8.14 & 9.73 & 8.63 \\
\hline
\end{tabular}
under imazapyr + imazapic residue doses

${ }^{*}$ Cotton was sown 135 days after application of herbicide at doses $75,150,225$ and $300 \mathrm{~g}$ ha

${ }^{n}$ Not significant by analysis of variance at 0.05 probability; means followed by the same letter in the column do not differ from each other at 0.05 of probability by the Tukey test

Table 3. Parameters of chlorophyll a fluorescence transients obtained by the JIP-test at 15 days after emergence (DAE) and 60

\begin{tabular}{|c|c|c|c|c|c|c|c|c|c|c|}
\hline \multirow{2}{*}{$\begin{array}{c}\text { Dose } \\
\left(\mathrm{g} \text { a.i. } \mathrm{ha}^{-1}\right)\end{array}$} & \multicolumn{5}{|c|}{15 DAE } & \multicolumn{5}{|c|}{60 DAE } \\
\hline & $\overline{\phi_{\mathrm{P}_{0}}}$ & ABS/RC & $\mathrm{Dl}_{0} / \mathrm{RC}$ & $\overline{\mathbf{P I}_{\mathrm{ABS}}}$ & $\mathbf{P I}_{\text {TOTAL }}$ & $\phi_{\mathrm{p}_{0}}$ & ABS/RC & $\mathrm{Dl}_{0} / \mathrm{RC}$ & $\mathrm{Pl}_{\mathrm{ABS}}$ & $\mathbf{P l}_{\text {lotal }}$ \\
\hline 0 & $0.81 \mathrm{a}$ & $19156 \mathrm{C}$ & $0.37 \mathrm{C}$ & 40787 b & 39186 b & $0.76 \mathrm{a}$ & $27909 a b$ & $0.67 a b$ & $12110 \mathrm{bc}$ & $15835 \mathrm{C}$ \\
\hline 75 & $0.81 \mathrm{a}$ & $18594 \mathrm{C}$ & $0.36 \mathrm{C}$ & $51269 \mathrm{a}$ & $51464 \mathrm{a}$ & $0.73 b$ & $28520 \mathrm{a}$ & $0.77 \mathrm{a}$ & $8438 \mathrm{c}$ & $25546 \mathrm{~b}$ \\
\hline 150 & $0.80 \mathrm{~b}$ & $21370 \mathrm{~b}$ & $0.44 b$ & 30822 c & $29637 \mathrm{~cd}$ & $0.77 \mathrm{a}$ & 25978 b & $0.61 \mathrm{~b}$ & 13542 b & 21389 bc \\
\hline 225 & $0.78 \mathrm{c}$ & $23309 a$ & $0.52 \mathrm{a}$ & $32275 \mathrm{C}$ & $25769 d$ & $0.78 \mathrm{a}$ & 25701 b & $0.58 \mathrm{bc}$ & $16306 \mathrm{~b}$ & $18191 \mathrm{C}$ \\
\hline 300 & $0.79 b$ & $21959 a b$ & $0.45 b$ & 34734 bc & $32649 \mathrm{c}$ & $0.78 \mathrm{a}$ & $22380 \mathrm{c}$ & $0.50 \mathrm{C}$ & $22584 a$ & $39380 \mathrm{a}$ \\
\hline CV (\%) & 0.69 & 3.96 & 4.46 & 9.38 & 8.36 & 1.33 & 4.17 & 7.73 & 16.08 & 12.81 \\
\hline
\end{tabular}
DAE for cotton cultivated with imazapyr + imazapic residues*

* Cotton was sown 135 days after application of herbicide at doses $75,150,225$ and $300 \mathrm{~g} \mathrm{ha}^{-1}$

${ }^{n}$ Not significant by analysis of variance at 0.05 probability; Means followed by the same letter in the column do not differ from each other at 0.05 of probability by the Tukey test. $\phi_{\mathrm{p}_{0}}-$ Maximum quantum yield for primary photochemistry; ABS/RC - Absorption flux (of antenna chlorophyll) per reaction centre (RC); DI $/ \mathrm{RC}$ - Dissipation of an active RC; $\mathrm{PI}_{\mathrm{ABS}}$ - Performance index (potential) for energy conservation from exciton to the reduction of intersystem electron acceptors; $\mathrm{PI}_{\text {total }}-$ Performance index (potential) for energy conservation from exciton to the reduction of PSI end acceptors 
inhibiting herbicide applied in pre-emergence on sandy loam soil in the southeast of the United States of America. Grey et al. (2005) found a negative exponential trend, where cotton height decreased as the imazapic dose was increased, with yields of seed cotton being reduced by more than $60 \%$ from applications of $5 \mathrm{~g}$ a.i. ha ${ }^{-1}$. These results indicated that soil type is a key factor in the response of cotton to imazapic. Matocha et al. (2003) reported a reduction in the height of the cotton on application of imazapic at 140 and $210 \mathrm{~g}$ a.i. ha ${ }^{-1}$, grown in rotation with peanut crops. Wiatrak et al. (2009) reported cotton height reduction in the first year due to high rates of imazapic application, but not in the second year. By contrast, Grichar et al. (2004) did not observe a reduction in growth of plants when subjected to herbicides imazapyr + imazapic.

Residue of herbicides of the imidazolinones group in the soil has been presented as a limiting factor in the traditional rotation of peanuts, wheat, corn and soybeans in China. For example, as indicated on product labels, wheat should only be grown 120 days after application, and corn, cotton and barley 540 days after application (Su et al., 2017). According to these authors, injuries to corn and cotton were observed in plants cultivated one year after application of imazapic to a peanut crop.

Metabolization of herbicides from the imidazolinones group is a particular concern in areas with low precipitation and low $\mathrm{pH}$ soils. Reduced soil moisture seems to limit the degradation of these herbicides, and absorption is reduced in low $\mathrm{pH}$ soils, which increases bioavailability and therefore increases the potential for injury in successor crops (Ball et al., 2003). In the present study, the initial $\mathrm{pH}$ of the soil prepared to receive the soybean crop was 5.80; therefore, below the ideal range tolerated by cotton crops, at around 7. This might have increased the availability of the herbicide in the soil and its residual potential, considering that the $\mathrm{pKa}$ values of
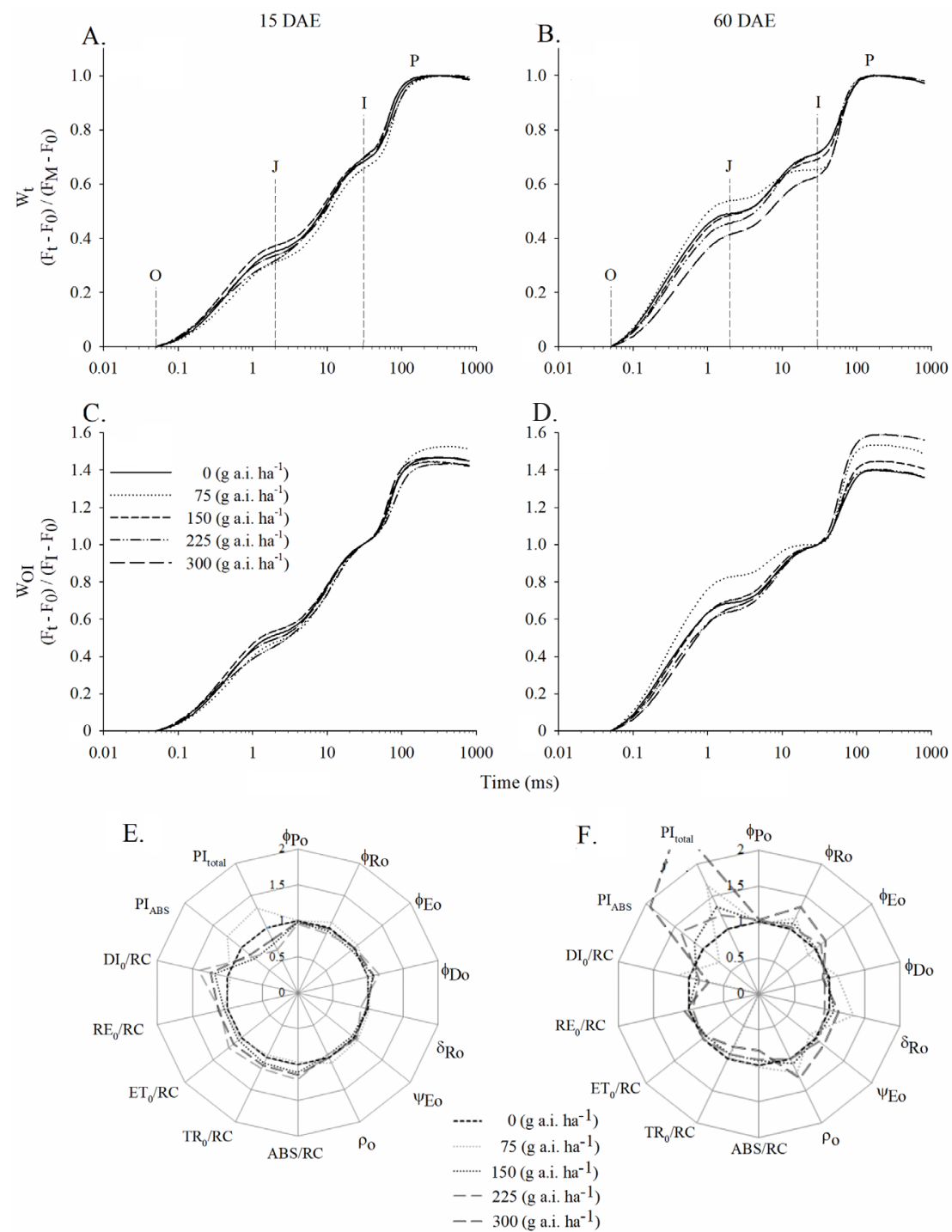

Values normalized to $1 \mathrm{~ms}$ (control) by the JIP-test $(\mathrm{n}=4)$; DAE Days after emergence. $\phi_{\mathrm{Po}_{\mathrm{o}}}$ - Maximum quantum yield for primary photochemistry; $\phi_{\mathrm{Ro}}$ - Quantum yield for reduction of end electron acceptors at the PSI acceptor side (RE). $\phi_{\mathrm{Eo}}$ - Quantum yield for electron transport (ET); $\phi_{\mathrm{Do}}-$ Maximum quantum yield of non-photochemical de-excitation; $\delta_{\mathrm{Ro}}$ Efficiency/probability with which an electron from the intersystem electron carriers moves to reduce end electron acceptors at the PSI acceptor side (RE); $\psi_{\mathrm{E}}$ - Efficiency/probability that an electron moves further than $\mathrm{Q} ; \mathrm{ABS} / \mathrm{RC}$ - Absorption flux (of antenna chlorophyll) per reaction centre (RC); TR/RC - Maximum trapping rate per RC; ET /RC - Electron transport of an active $\mathrm{RC} ; \mathrm{RE}_{0} / \mathrm{RC}$ - Electron flux reducing end electron acceptors at the PSI acceptor side, per RC; $\mathrm{DI}_{0} / \mathrm{RC}-\mathrm{Dissipation}_{\text {of }}$ an active RC; $\mathrm{I}_{\mathrm{ABS}}$ - Performance index (potential) for energy conservation from exciton to the reduction of intersystem electron acceptors; $\mathrm{PI}_{\text {total }}$ - Performance index (potential) for energy conservation from exciton to the reduction of PSI end acceptors

Figure 2. Chlorophyll a fluorescence variable transient in cotton plants grown under different doses of a commercial mixture of the herbicides imazapyr + imazapic. Relative variable fluorescence between steps $\mathrm{O}$ and $\mathrm{P}(\mathrm{A}$ and $\mathrm{B})$ and between steps $\mathrm{O}$ and I (C and D) and transient chlorophyll fluorescence parameters obtained by the JIP-test at 15 DAE (E) and 60 DAE (F) 
imidazolinone herbicides range from 1.3-3.9. In addition, a soil $\mathrm{pH}$ higher than the $\mathrm{pKa}$ of the herbicide would cause a greater amount of the herbicide to be in the anionic form, and hence available in the soil solution.

The cotton crop showed a decrease in transient fluorescence emission. This was evident in absolute values at 15 days after emergence at the JIP point for plants on soil treated with half the maximum marketed dose (75 $\mathrm{g}$ a.i. $\left.\mathrm{ha}^{-1}\right)$, in comparison to control plants. By contrast, plants on soils treated with $225 \mathrm{~g}$ a.i. ha ${ }^{-1}$ herbicide could not be differentiated from the control at the I-step and those on soils treated with $75 \mathrm{~g}$ a.i. ha ${ }^{-1}$ herbicide did not differ from the control treatment at the P-step (Figures $2 \mathrm{~A}$ and $\mathrm{C}$; Table 2).

At 60 DAE, only plants subjected to treatments 75 and $225 \mathrm{~g}$ a. i. ha ${ }^{-1}$ showed differences; however, they did not differ from the control. The transient fluorescence emission curves of chlorophyll a did not differ between the doses tested and the control treatment at J-step (Table 2; Figures 2B and D).

The JIP-test parameters obtained at 15 DAE for cotton showed that plants subjected to soils treated with 150, 225 and $300 \mathrm{~g}$ a. i. ha ${ }^{-1}$ herbicide declined in maximum quantum yield of primary Photosystem II photochemistry $\left(\phi_{\mathrm{P}_{0}}\right)$ and photosynthetic performance indices $\left(\mathrm{PI}_{\mathrm{ABS}}\right.$ and $\mathrm{PI}_{\text {total }}$; Table 3). By contrast, the size of the antenna complex (the total number of photons absorbed by chlorophyll molecules of all reaction centres (RCs) divided by the total number of active $\mathrm{RCs} ; \mathrm{ABS} / \mathrm{RC}$ ) and energy dissipation (dissipated energy flux per $\mathrm{RC} ; \mathrm{DI}_{0} / \mathrm{RC}$ ) in the form of heat increased in these treatments in relation to the control (Table 3 ), suggesting that the plants might have shown initial sensitivity to the presence of herbicides in the soil. These herbicides characteristically acted in the early stages of plant development. Notably, plants cultivated on soil treated with $75 \mathrm{~g}$ a. i. ha ${ }^{-1}$ herbicide showed an increase in photosynthetic performance indexes $\left(\mathrm{PI}_{\mathrm{ABS}}\right.$ and $\left.\mathrm{PI}_{\text {total }}\right)$ in relation to the control and other treatments at 15 DAE (Figure 2E).

Plants grown on soil treated with $300 \mathrm{~g}$ a. i. ha-1 herbicide, $60 \mathrm{DAE}$, showed a smaller antenna complex size (ABS/RC) and lower energy dissipation in the form of heat ( $\left.\mathrm{DI}_{0} / \mathrm{RC}\right)$. On the other hand, they showed higher indexes of photosynthetic performance $\left(\mathrm{PI}_{\mathrm{ABS}}\right.$ and $\left.\mathrm{PI}_{\text {total }}\right)$. The size of the antenna complex also decreased in plants grown in soils treated with 150 and $225 \mathrm{~g}$ a. i. ha-1 herbicide (Figure 2F; Table 3).

Baker (2008) suggests that for herbicides that do not act on the photosystem, the reduction in electron flux is not caused by a reduction in the photochemical activity of the photosystem, but instead, is probably due to energy deficiency for carbon assimilation in photosynthesis. There is evidence that many inhibitors of metabolic processes, which are not directly involved in photosynthetic metabolism, can produce changes in the induction of fluorescence kinetics (Barbagallo et al., 2003).

According to Oukarroum et al. (2007), the performance indexes of photosynthetic are considered more sensitive in the detection of environmental stress in plants, since they relate to the efficiency of absorption, capture, and transfer of excitation energy by photosystem II. Therefore, the decrease in photosynthetic performance indexes of plants cultivated in soils treated with 150, 225 and $300 \mathrm{~g}$ a. i. ha ${ }^{-1}$ imazapyr + imazapic herbicide at $15 \mathrm{DAE}$, and $75 \mathrm{~g}$ a. i. ha ${ }^{-1}$ at $60 \mathrm{DAE}$, indicated the photoinhibitory effect of these herbicides on plants, with a reduction of $\mathrm{PI}_{\mathrm{ABS}}$ reflecting a reduction of electron flow in the electron transport chain (Chen et al., 2014).

\section{Conchusions}

1. Cotton growth was not affected by the residues of the herbicides in the soil.

2. Imazapyr + imazapic herbicides caused photoinhibitory effect on cotton plants grown 135 days after the pre-emergence application.

3. Persistence of the herbicide in the soil did not cause a carryover effect.

\section{Literature Cited}

Abouziena, H. F.; Haggag, W. M. Métodos alternativos de controle não químicos de plantas daninhas: Uma revisão. Planta Daninha, v.34, p.377-392, 2016. https://doi.org/10.1590/S010083582016340200019

Baker, N. R. Chlorophyll fluorescence: A probe of photosynthesis in vivo. Annual Review Plant Biology, v.59, p.89-113, 2008. https:// doi.org/10.1146/annurev.arplant.59.032607.092759

Ball, D. A.; Yenish, J. P.; Alby, T. Effect of imazamox soil persistence on dryland rotational crop. Weed Technology, v.17, p.161-165, 2003. https://doi.org/10.1614/0890-037X(2003)017[0161:EOIS $\mathrm{PO} 2$ 2.0.CO;2

Barbagallo, R. P.; Oxborough, K.; Pallett, K. E.; Baker, N. R. Rapid, noninvasive screening for perturbations of metabolism and plant growth using chlorophyll fluorescence imaging. Plant Physiology, v.132, p.485-493, 2003. https://doi.org/10.1104/pp.102.018093

Chen, S.; Strasser, R. J.; Qiang, S. In vivo assessment of effect of phytotoxin tenuazonic acid on PSII reaction centers. Plant Physiology Biochemistry, v.84, p.10-21, 2014. https://doi. org/10.1104/pp.102.018093

Dan, H. de A.; Dan, L. G. de M.; Barroso, A. L. de L.; Procópio, S. de O.; Oliveira Júnior, R. S. de; Braz, G. B. P.; Alonso, D. G. Atividade residual de herbicidas usados na soja sobre o girassol cultivado em sucessão. Ciência Rural, v.42, p.1929-1935, 2012. https://doi. org/10.1590/S0103-84782012005000081

Dovala, A. C.; Monteiro, A. Controle químico de Striga asiatica por recurso a sementes revestidas de milhos resistentes ao imazapir. Revista de Ciências Agrárias, v.36, p.466-474, 2013.

Grey, T. L.; Braxton, L. B.; Richburg, J. S. Effect of wheat herbicide carryover on double-crop cotton and soybean. Weed Technology, v.26, p.207-212, 2012. https://doi.org/10.1614/WT-D-11-00143.1

Grey, T. L.; Prostko, E. P.; Bednarz, C. W.; Davis, J. W. Cotton (Gossypium hirsutum) response to simulated imazapic residues. Weed Technology, v.19, p.1045-1049, 2005. https://doi. org/10.1614/WT-04-256R1.1

Grichar, W. J.; Besler, B. A.; Baughman, T. A.; Dotray, P. A.; Lemon, R. G.; Senseman, S. A. Cotton response to imazapic and imazethapyr residues following peanut. Texas Journal of Agriculture and Natural Resources, v.17, p.32-39, 2004. 
Matocha, M. A.; Grichar, W. J.; Senseman, S. A.; Gerngross, C. A.; Brecke, B. J.; Vencill, W. K. The persistence of imazapic in peanut (Arachis hypogaea) crop rotations. Weed Technology, v.17, p.325329, 2003. https://doi.org/10.1614/0890-037X(2003)017[0325:T POIIP]2.0.CO;2

Oukarroum, A.; Madidi, S. E.; Schansker, G.; Strasser, R. J. Probing the responses of barley cultivars (Hordeum vulgare L.) by chlorophyll a fluorescence OLKJIP under drought stress and re-watering. Environmental and Experimental Botany, v.60, p.438-446, 2007. https://doi.org/10.1016/j.envexpbot.2007.01.002

Ramos, G. A.; Barros, M. A. L.; Kouri, J.; Santos, R. F. Cultivo do algodão irrigado. In: Bezerra, J. R. C. (ed.). Sistemas de produção. Campina Grande: Embrapa Algodão, 2014. 58p.

Senseman, S. A. Herbicide handbook. 9.ed. Lawrence: Weed Science Society of America, 2007. 458p.

Silva, D. V.; Santos, J. B.; Ferreira, E. A.; Silva, A. A.; França, A. C.; Sediyama, T. Manejo de plantas daninhas na cultura da mandioca. Planta Daninha, v.30, p.901-910, 2012. https://doi.org/10.1590/ S0100-83582012000400025
Strasser, R. J.; Govindjee. The Fo and the O-J-I-P fluorescence rise in higher plants and algae. In: Argyroudi-Akoyunoglou, J. H. (ed.). Regulation of chloroplast biogenesis. New York: Plenum Press, 1992. Chap.61, p.423-426. https://doi.org/10.1007/978-1-4615-3366-5_60

Su, W. C.; Sun, L. L.; Wu, R. H.; Ma, Y. H.; Wang, H. L.; Xu, H. L.; Yan, Z. L.; Lu, C. T. Effect of imazapic residues on photosynthetic traits and chlorophyll fluorescence of maize seedlings. Photosynthetica, v.55, p.294-300, 2017. https://doi.org/10.1007/s11099-016-0641-3

Tsimilli-Michael, M.; Strasser, R. J. Vivo assessment of stress impact on Plants'Vitality: Applications in detecting and evaluating the beneficial role of mycorrhization on host plants. In: Varma, A. (ed.). Mycorrhiza: State of the art, genetics and molecular biology, eco-function, biotechnology, eco-physiology, structure and systematics. Heidelberg: Springer, 2008. Chap.32, p.679-703. https://doi.org/10.1007/978-3-540-78826-3_32

Wiatrak, P. J.; Wright, D. L.; Marois, J. J. Influence of imazapic herbicide simulated carryover on cotton growth, yields, and lint quality. Crop Management, v.8, p.55-70, 2009. https://doi. org/10.1094/CM-2009-0720-01-RS 